\title{
Limits and Contradictions of Post-developmentalism as a Heterodox Approach to Capitalist Development
}

Juan M. Ramírez-Cendrero

Complutense University of Madrid, Faculty of Economics and Business (jmramirezcendrero@ucm.es)

\begin{abstract}
In recent years, debates around development have seen the growing prominence of post-developmentalist proposals, which are driving the anti-capitalist discourse and at the same time serving as a springboard for non-capitalist development proposals. However, the search for an alternative approach to development can disrupt the construction of viable action strategies and dilute important elements of the contributions advanced by the heterodox tradition, mainly Marxist. The aim of this paper is to systematize the limitations of post-developmentalism and articulate a heterodox paradigm that can be measured in tandem with conventional and hegemonic approaches in development studies, such as approaches stressing human development.
\end{abstract}

Keywords: post-developmentalism; degrowth; development theory; capitalism 


\section{Introduction}

In the context of current debates around development, post-developmentalist proposals have been gaining wide dissemination and influence. In fact, forums, associations, academics and social activities identified with post-development have grown considerably in recent years. The collective Revue Silence in France, the group Recerca i Decreixement (Research and Degrowth) in Spain, the movements in favor of the "simple living" or "downshift" in the United States and Canada, as well as the organizations promoting agroecological cooperatives and associations for the establishment of urban gardens for self-provision in big cities, are all examples of the way in which some approaches related to post-development are being disseminated.

In addition, prominently in Latin America, reflections about the nature of development have acquired theoretical solidity and found correspondence in some political processes in the region, processes that are explicitly observable in Venezuela, Ecuador and Bolivia, and to a lesser extent in Brazil and Argentina. Taken together, these processes make up the scenario where post-developmentalist approaches have progressed the most, as can be seen in claims of pre-Columbian past or the in rejection of development as a simple Eurocentric reflex.

However, a significant portion of post-developmentalist approaches are limited to the theoretical level, specifically to challenging and deconstructing the idea of development as a dominant "discourse" of Western modernity that essentially serves the expansion and legitimation of the capitalist economic system. This is clearly reflected in one of the central arguments of post-developmentalist analysis, namely the identification of development and growth with capitalist development itself (Latouche 2007; Rist 2002; Trainer 2011).

The post-development paradigm is based on several arguments (Corbridge 1998; Sachs 1992). First, post-developmentist authors think that development has consisted of "bad" change and "bad" outcomes through the imposition of Western ethnocentric notions of development upon the Third World. Second, this perspective emerged as a reaction to the deliberate efforts in progress made in the name of 
development since World War 2. These efforts had been a failure of enormous dimensions, a Frankensteinian dream (Escobar 1992a) which revealed the ecological, economic and social impossibility of achieving the life and consumption standards of the most industrialized economies for the entire planet. Third, the postdevelomentalist approach is not so much a conceptualization of development as a frontal assault against the "development industry" (including researchers, practitioners and aid institutions).

In this way the traditional heterodoxy, mainly Marxist, of development economics became overwhelmed by a new heterodoxy which denounced not a particular form of development but rather development itself, now identified as capitalist development. While the Marxist analyses criticized the adjective (capitalist), the new heterodoxy focused its criticism on the noun (development), calling the idea of capitalist development redundant because development in the prevailing sense can only be capitalist (Rist 2002; Sachs 1992). All of this opened a debate in the dissenting field of development that can be seen in terms of alternative development vs. alternatives to development. However, contributions from post-developmentalism have been scarce in the realization of specific strategies consistent with an alternative orientation to development. This pre-positive shortage hinders clarification of the debate between alternative development and alternatives to development. Much controversy becomes diluted, however, when concrete experiences of action and transformation are analyzed. In such cases the choice of label may lose importance: Alternative development or alternative to development? In either case, beyond capitalist development. ${ }^{1}$

The strength that post-developmentalist proposals such as de-growth have achieved in recent years poses a challenge for critical areas of Development Economics, which have historically nourished proposals including dependentism (especially those inspired by neo-Marxism) or structuralism (especially the audacious structuralism of the more recent work of Raul Prebisch, Celso Furtado, or Pedro Vuskovich). Moreover, the heterogeneous tradition of Third World theories (such as

\footnotetext{
${ }^{1}$ Indeed, some practices of economic and social organization implemented in Latin America can be characterized both as an expression of alternative development and as an alternative to development (García, Ramírez-Cendrero and Santillán 2015).
} 
Bandung, or the Commission of the South), which have largely been inspired by certain dependentist and especially structuralist contributions.

The years following the Washington Consensus stage in debates about development exhibited a gradual recovery from the reflexive impulses of Development Economics, strengthening such contentious proposals as crystallized in the World Social Forum of Porto Alegre, or the anti-globalization assertion that "another world is possible." Such post-developmental analysis and de-growth proposals also gained prominence with the revival of positions regarding neo-liberalism, its sequels such as the Washington Consensus, and other legitimizing approximations of the status quo such as notions of human development.

Certainly, the cumulative advances in global awareness around the environmental limits of human economic activity, and the systematization and increasing elaboration of theoretical proposals on the role of Nature in human life (Ecological Economics), have contributed to the increasing diffusion and acceptance of post-developmentalist approaches (Escobar 1995; Leff 2008; Martínez Alier 2009; Riechmann 1995; Roca 2007). In recent years development debates have therefore been more attendant to the increasing stature of post-developmental proposals, in particular as alternatives to development, while the post-developmental approach has been driving an anti-capitalist discourse (Latouche 2008; Taibo 2009). However, as I intend to show in this paper, altering the search for an alternative (non-capitalist) development in favor of ill-defined alternatives to development can disarticulate the construction of feasible strategies and dilute many of the contributions already consolidated by the heterodox tradition of development economics.

The objective of this work is to systematize the limitations of postdevelopmentalism in order to articulate a heterodox paradigm that can be measured through conventional and hegemonic approaches in development studies, such as the human development approaches. To this end I argue that the post-developmental critique does not provide the necessary elements to transcend capitalism, and many of its proposals can co-exist and be compatible with capitalism. Ultimately, then, postdevelopmentalism can be consistent with the interests of the privileged. This article is 
a reflection of the current debates on development. Particularly, it is associated with efforts to reconstruct and encourage dissenting proposals for development, and with the formulation of developmental as well as emancipatory alternatives to capitalism. In short, the main contribution of this work will not be to present a critical review of the post-developmental literature ${ }^{2}$ but to assess the potential for configuring a robust and influential approach to the construction of liberating alternatives.

This critical exercise must be based on three initial statements: 1) the uncertain viability of the "pure" post-developmental proposals, as seen in the kawsay sumak lessons from Ecuador (Breton 2013; García, Ramírez-Cendrero, and Santillán 2015) or in proposals on the so-called rights of Nature (Acosta 2010); 2) the existence of spaces for an alternative to capitalist development; and 3) clarification of identification between alternatives to development and alternatives to capitalism-key to the diagnosis and to post-developmental proposals derived from the assertion that "antidevelopmentalism is today the only anti-capitalism" (Amorós 2012, 29; Ceceña 2013; Taibo 2014).

First, I systematize the main arguments of post-developmental narrative as the expression of a post-structuralist turn within development studies. Next, I identify the main limitations of post-developmentalism to articulate an emancipatory approach with interpretative and political power with which to build alternatives to capitalist development. Finally, I present several conclusions.

\section{The Post-Structuralist Turn in Development: Post-Developmentalism}

Critical development economics in the 1960s, 1970s, and early 1980s was dominated by Marxist theories on the world economy, underdevelopment, and dependenceespecially theories of dependency and the global system and its derivations. ${ }^{3}$ From these theoretical premises the analysis of development looked for holistic explanations through which to coherently integrate global economic dynamics (accumulation on a

\footnotetext{
2 There are seminal works in this regard, among which must be noted Corbridge (1998), Parfitt (2002), and Pieterse (1998). In our case, unlike in these works, criticism of post-developmentalism arises from the claim of an emancipatory horizon and therefore goes beyond the merely academic space. ${ }^{3}$ Among the overwhelming literature it is necessary to highlight some contributions of reference to guide the study of all these authors: Blomström and Hettne (1984) and Seers (1981).
} 
worldwide scale, uneven development or international division of labor) with the characterization and evolution of national economies, divided between a capitalist core and an underdeveloped, dependent periphery. These very generalizing theories interpreted every historical phenomenon and every economic feature as a component of a larger entity, namely the capitalist world economy subject to its own internal logic of a dynamic reflected in regularities (structural trends, economic laws) that allowed for an understanding of the totality of current economic realities. This approach to tackling the interpretation of economic reality and its expressions, such as underdevelopment and dependence, reflected the culmination of the modern radical social philosophy, the most audacious heir to the Enlightenment and $19^{\text {th }}$-century European positivism, which aspired to a comprehensive understanding of the global economic reality through the universalization of its characteristics (like rationality) and the complex social mechanisms they generated.

New approaches started to forcefully emerge back in the 1980s. These approaches were very skeptical of holistic interpretations, such as those formulated from Marxism, that give priority to the action of social relations over the will of human beings and their capacity to shape reality from symbols and concepts. ${ }^{4}$ Thus, poststructuralist interpretations arose which conceived a reality composed by complexities and discontinuities rather than by linear and coherent regularities. Faced with such holistic analysis without which the nature of the parties involved (cornerstone of structuralism) could not be understood, post-structuralist authors sought to restore the prominence of uniqueness (of individuals, events, concepts). And while the Marxist critique denounced the capitalism with economic language, the post-structuralist critique used cultural language to denounce capitalist modernity.

This contrast also reached into the perception of development. While Marxist theories assign an emancipatory nature to development, post-structuralism identifies it as a strategy of power for its reproduction and social control. Ultimately, the poststructuralist critique expresses disenchantment and loss of confidence in modern meta-narratives and broadly collective concepts (development, emancipation, world

\footnotetext{
${ }^{4}$ Baudrillard (1983) notes that signs and cultural codes were the original constituents of social life, much more than the social relations established in material production. This was the route by which poststructuralist thinkers sought to escape Marxism.
} 
system, dependency, national liberation) to which Marxist theories of development gave full expression.

This post-structuralist shift in development studies has been expressed in both post-developmentalist proposals and analysis, including by one of its main derivations, de-growth. There are many theoretical backgrounds to post-developmentalism and several works that offer a fairly comprehensive approach to its principles. Pieterse (1998), Peet and Hartwick (1999), and especially Corbridge (1998) present a systematic ordination and assessment of the most influential contributions of this current. In addition, Garcia (2012) and Latouche (2008) identified the fundamentals originating in de-growth. The post-structuralist turn in development studies can be understood as the confluence of several streams of thought: the fundamentals of philosophy of postmodernity, the socio-historical and anthropological critique to development, and the environmental critiques of the effects of economic growth on Nature. Thus, postdevelopmentalism cannot be understood without post-structuralist thought, and it also converges with feminism and radical environmentalism to reject both orthodox theories of development and proposals derived from alternative approachesincluding the Marxist theories, traditionally hegemonic among the dissenting approaches to development.

First, the critique of modernity by Ivan Illich (1997) questioned the benefits that the modern world, including systems of universal public health or education, ${ }^{5}$ might extend to all countries, especially non-Western ones. Illich understood underdevelopment not as an insufficient standard of living (as it was understood in the post-war period), but as a form of consciousness, a mental state in which social needs are turned into commodities that most of society aspires to achieve but never does. ${ }^{6}$ For Illich, in struggle against the universality of values and concepts it was not necessary to establish universal utopian rules, as development has been understood in general. Instead, the aim should be the establishment of formal conditions for a

\footnotetext{
${ }^{5}$ For Illich, universal healthcare endagered individual autonomy and created dependence on the state or the system.

6 "We have embodied our world view in our institutions and we are now their prisoners. Factories, news media, hospitals, governments and schools produce goods and services packaged to contain our view of the world. I-the rich-conceive of progress as the expansion of these establishments" (Illich 1997, 95).
} 
process that would allow any community to continuously choose its own attainable utopia. Thus, local particularities would not be diffused in or liquidated by the universalism of development, or by those concepts that represented emancipatory and utopian longing, such as national liberation, socialism, or revolution.

Second, since the 1980s authors emerged who evaluated very negatively the results of developmental strategies applied after 1945. In this way, the aspiration of development was impugned and labeled chimerical. The dream of development became a nightmare to some authors who understood it as Westernization, a Eurocentric imposition upon the world. Socio-historical critiques to development branded it a religion, or modern belief system (Rist 2002), an invented story (W. Sachs 1992), a cultural expression that concentrated a set of economic and social practices proper to Western capitalist countries into a legitimizing discourse for said practices (institutional, ideological, academic) -into the universalization of capitalist development. From an anthropological perspective the concept of development was therefore criticized as a cultural and conceptual expression of Western colonialism, with a perceived need to decolonize the collective conception of development (Escobar 1995) and to understand that apparent cultural poverty need not be considered true poverty (Shiva 1988). All these post-developmentalist authors denounced the imposition of a Western eurocentric vision of development on the rest of the world, a vision further identified with modernity and presented by Western discourse as superior to non-Western tradition.

Third, the post-structuralist turn in development studies also relied on analysis derived from complaints about the environmental effects of development on Nature. In such analyses such contributions as bioeconomy (Georgescu-Roegen 1975) or ecodevelopment (Sachs 1980) converge to highlight the impossibility of infinite economic growth on a planet with physical limits, thus forcing us to contemplate the physical and environmental repercussions of economic activity. Advocates of degrowth will conclude that these limits force the abandonment of development as a social objective, assuming it to be unviable and incompatible with these restrictions, and therefore seeing the term "sustainable development" as an oxymoron. The conceptual, interpretative, and strategic implications of this analysis surely impel 
degrowth as a strongly attractive focus among critics of both capitalist development and the forms of urban and industrial life typical of the core economies (Hamilton 2006; Trainer 2011).

From these sources of inspiration, post-developmentalism, as a heterogeneous expression ${ }^{7}$ of the post-structuralist turn in development studies, can be reflected upon through four key aspects. ${ }^{8}$

First, post-developmentalism represents a Copernican shift in perception and attitudes toward development, because development will be understood as a dominant discourse of Western modernity rather than a pursuit within development studies. Since post-developmentalism is primarily a reaction to modernity, the key to postmodernist condemnations of development is its very identification with modernity, presented in Western discourse as a superior condition. Development would, in short, constitute a natural Westernization of the world ${ }^{9}$ through the spread of capitalist economic growth (Rist 2002; Sachs 1992). From this perspective, development and poverty are social constructions that do not exist in the objective sense outside of the discourse ${ }^{10}$ (body of ideas, concepts and theories) on development, and they can thus only be known through the discourse (Escobar 1992b, 1995; Rahnema 1997). From here is derived a frontal attack on the development industry, including on researchers, policymakers, managers, and development agencies. For these authors, "it is time to recognize development as malignant myth," in so far as "the "three decades of development' have been an irresponsible experiment that has failed miserably" (Esteva 1985, 78).

Secondly, the criticism of modernity in post-developmentalism extends to significant aspects of the Enlightenment, especially universalism and the tendency to proclaim the validity of certain categories irrespective of cultures or local specificities of where they are expressed. This will suppose a rejection of materialism as a worldview

\footnotetext{
7 "Post-development is by no means a homogeneous current" (Pieterse 1998, 361).

${ }^{8}$ Two collective publications of reference, authentic seminal works of the post-structuralist turn in development, are Sachs (2002) and Rahnema and Bawtree (1997). See also Rist (1996).

9 "From the start, development's hidden agenda was nothing more than Westernization of the world ... The mental space in which people dream and act is largely occupied today by Western imagery" (Sachs 1992, 3-4).

10 "Poverty is a myth, a construct and the invention of a particular civilization" (Rahnema 1997, 158).
} 
and of political economy as a social science. It largely explains the distance between post-developmentalism and Marxism: for post-developmentalists, Marxism would lock local particularities into a rigid corset modeled according Eurocentric criteria. In short, the anti-modern discourse considers that the rejection of capitalism should be based on local and traditional cultural values, and not on some novel Eurocentric universalism (though it be anti-capitalist) such as Marxism.

Third, post-developmentalism proposes a revaluation of traditional noncapitalist societies; ultimately, life in the undeveloped world is viewed not as bad but on the contrary-the allowance of a free fulfillment and satisfaction that development sought to ruin (Kiely 1999; Peet and Hartwick 1999). Thus, post-developmentalism tends to relativize the value of certain essential aspects of what has traditionally been understood as progress, while also vindicating traditional modes of thought and social practice previously condemned or relegated into the past precisely in the name of progress.

Finally, post-developmentalism will boost alternative reflections on what is, or should be considered, a good life. In this sense the wager is that a good life is associated with localities in contact with the land, and with local communities, according to the "Gandhian notions of beauty, frugality and simplicity" (Corbridge 1998, 139). That simple life (simple living in Sachs (1997) or simpler way in Trainer (2011)) is presented in two versions: the ecological and the spiritual. The ecological dimension requires a drastic, fast and powerful reduction in the use of natural resources as the way to a "revolution of sufficiency," which involves both rationalization of the means and extreme moderation in the aims (Sachs 1997). For its part, the spiritual dimension of the good life involves relegating the material, subordinating it to an ideal of beauty that is essentially intangible and not dependent on consumption (Gandhi 1997). All this implies a notion of the good life as associated with the peace and the harmony that might be achieved through simplicity, with less materialistic lifestyles, and where the pursuit of happiness should be associated with spiritual sources rather than consumption patterns. 
Having examined these two inspirational backgrounds as distinctive aspects of the post-developmentalist approaches, I next consider the weaknesses found in an emancipatory perspective that assumes the overcoming of capitalist development as feasible horizon.

\section{Limits and Weaknesses of Post-Developmentalism}

Much criticism has been made of works inspired by post-developmentalism, whether in terms of their philosophical foundation (post-structuralism), the consistency of their analysis, the essence of their interpretation, or the reach of their proposals (Corbridge 1998; Kiely 1999; Parfitt 2002; Pieterse 1998, 2000). This paper, as mentioned in the introduction, presents a critique of post-developmentalist analyses and proposals through acknowledgement of their limitations as potential inspiration for an emancipatory alternative to capitalist development, or to hegemonic approaches in the field of development, in terms both interpretative and political.

In general, the post-developmentalist critique does not provide the elements necessary to transcend capitalism. On the contrary, many of its proposals can co-exist and be compatible with capitalism. What I argue is that ultimately postdevelopmentalism can function as "an ideology consistent with the interests of the privileged" (Amin 1997, 165). The global polarization inherent in capitalism requires that powerful transition strategies consider the totality of factors present in a contradictory double-challenge: on the one hand, the need to develop productive forces and, on the other, the need to design alternative social relationships that overcome exploitation. I find that post-developmentalist proposals do not provide answers to this double and contradictory challenge. To justify this position, several aspects must be considered.

A. The critique of capitalist development has historically originated and drawn support from contributions precedent to post-developmentalism (basically, neo-Marxism in its various lines). Some of these contributions have been adopted by postdevelopmentalism, although with severe interpretative weaknesses drawn from the relegation of central aspects of the capitalist economic process, especially globally. 
The post-structuralist turn of development was not the result of a critique focused on capitalism. As shown in the previous section, this turn was supported by other factors that subsequently gave rise to a nominally anti-capitalist discourse. The anti-capitalist critique came before the post-structuralist turn in development studies. Analysis of the contradictions and effects of capitalist development, and of the polarization of the world economy, have traditionally been nourished by contributions from Marxist theories of development, mainly those associated with aspects of dependency, the global system or modes of production.

Contributions to analysis of the center/periphery factor, inspired by postdevelopmentalism (mainly from the perspective of degrowth), have been circumscribed through issues such as ecological debt (González Reyes 2010; Martínez Alier 2009), overcoming the ethnocentrism of development (Rahnema 1997; Shiva 1988), or dependence, considered "primarily more cultural than economic" (Latouche $2008,228)$. However, the core generating processes of uneven development and global economic polarization (that is, forms of capitalist accumulation within the global economic process) have not been a central issue of such contributions.

B. Post-developmentalist authors do not include analysis of social classes and capitalist accumulation, giving critical priority to aspects of capitalist economic dynamics (such as the spendthrift character of opulent consumption) but not to its core, exploitation. Despite a nominally anti-capitalist discourse, the emphasis placed by postdevelopmentalist authors on super-structural aspects (such as the conceptual plurality or relativity of social constructions or, in economic terms, consumption patterns or industrialism) glosses over capital/labor relations, the core of capitalist exploitation and the traditional axis of heterodox analysis and anti-capitalist struggles, thus diluting a determinant contradiction of capitalism. In this regard, Hamilton (2006) is very instructive in positing the existence of two Lefts: the traditional Left, which sees society through a rich-vs-poor prism; and another, which explains the contemporary world and its challenges via the prism of waste and excessive consumption. According to this "second Left," the fundamental conflict is between the cultural/political influence of big business and the demand for genuine democracy, personal autonomy, and protection of natural and cultural values. Therefore, an appropriate organizational 
response must take the form of new social movements that call into question the political and cultural influence of big business. In this way central aspects of capitalist exploitation (like labor markets or ownership of the means of production) go unchallenged; that is, the conditions of production and appropriation of surplus value (wages, productivity, working conditions) remain outside the analysis. All these issues are subjugated by the interpretive priority of consumption patterns and their configuration and enforcement, or by industrialism-undoubtedly relevant aspects, but presented in a way that disconnects them from the core of capitalist accumulation. Post-developmentalism thus discards class analysis. Neither social class nor exploitation is covered by its interpretations, suggesting that the problem may lie in homo sapiens ${ }^{11}$ and not in capitalism. This means, for example, that the global population rather than the economic power structures is responsible for the deterioration of the planet, even though it is those structures which manage capitalism and which make decisions precisely by virtue of private ownership of the means of production.

In this sense, Hamilton (2006, 313) expresses very clearly that "today, the defining battle is not waged as between proletarians and capitalists for the division of the surplus generated in the production process, but by focusing on how to lead a genuine life in a social structure that prizes 'individuality' and superficiality." From this diagnosis, the conclusion is clear: "Now that the economic problem has been solved in rich countries, the focus of political debate and social change must leave the field of production and forms of ownership" (Hamilton 2006, 215)-being instead geared towards patterns of resource use in the field of production or towards trade patterns and consumption in the area of circulation, as the best ways to combat and overcome the most predatory and inhumane features of capitalism. This suggests that the presumed anti-capitalist character of degrowth could be considered a kind of voluntarism rather than a genuine criticism of the foundations of capitalism. In fact, proposals such as responsible consumption, promotion of local exchange networks, or

\footnotetext{
${ }^{11}$ Referring to an interview with paleontologist Jordi Agustí in which he states that "the 'homo sapiens' runs the risk of dying of success." See Público, April 13, 2010. All translation by the author unless otherwise stated.
} 
reduction of contaminant mobility, among others, do not necessarily imply a social rupture. On the contrary, not only are they compatible with capitalism, they may even provide it with a palatable varnish that can ideologically disarm and demobilize militant sectors of the working class, diluting their demands via a set of short-term and heterogeneous demands collected under the umbrella of citizenship. From these proposals unanswered questions are ultimately derived: Might an ethical, assistive, and responsibly green "capitalism with human face" be possible, or even desirable? Would it be feasible if ambitious criteria were strictly enforced on ethical, social, or environmental terms? If so, could this mean the end of capitalist exploitation?

C. There are many uncertainties in post-development around the subject of collectivity. Post-developmentalist analysis, especially the degrowth current, is more consistent with urban or petty-bourgeois individualism than with the demand for a genuine transformation of capitalism. The hierarchization of conflicts has an impact on identification of the subject of transformation. A working class overwhelmed by the amalgamation of new conflicts wonders whom post-developmentalist authors view as transformative players. What strategies are formulated? Undoubtedly, from postdevelopmentalist analysis a horizon derives more from individual response or resistance than from collective emancipation and social transformation. Indeed, there are proposals (such as those representing the version of degrowth found in Trainer 2011) which directly appeal to the petty-bourgeois and to urban individualism, superactivist and hyper-conscious, and therefore voluntary. This character is also present in the demand for downshifting, reducing work time, wages, and consumption, or in the proposal for "eudaemonism," meaning "happiness policy" (Hamilton 2006). The call for actions and pluralistic answers, diverse and local, typical of authors like Escobar (1992b) and Latouche (2007), could hardly constitute a sufficiently solid alternative with which to challenge capitalist development at the global level. Call for responsible consumption or raising recycling awareness are further examples of this. I do not want to deny the importance of these proposals to promote solidarity individual behavior, but it is necessary to ask about their true scope and anticapitalist potential. Indeed, individual behavior can be an instrument of pressure in the market that sends signals to companies, forcing them to mitigate some of their less-responsible behavior. But 
the commercial sphere is only one dimension of the system, and consumer response as an active (but individualized) social agent has little effect on other dimensions of capitalism (production, distribution). One can hardly assume any strategy for responsible consumption that continues to co-exist with irresponsible production, distribution or financing to be a holistic or emancipatory alternative to capitalism. Ultimately, strategies such as responsible consumption represent the conversion of workers into citizens with consumer awareness but without class. Indeed, if workers voluntarily a more austere life with less income as part of the generalized practice of responsible consumption, the result could be a reduction in the cost of the labor force ${ }^{12}$ and therefore an increase in capitalist exploitation. A strategy of responsible consumption that can deprioritize the importance of wages to the working class clearly lacks emancipatory force, and might also be demobilizing, even if it intends to contribute to individual or local awareness about the environmental limits of the planet.

These types of local or individual response, which require voluntaristic hypersensitization, are ultimately an expression of what Latouche $(2007,78)$ finds necessary to "decolonize our minds to really change the world." Indeed, this is the alternative that Latouche himself calls "voluntarist." But if the working class does not comply with such multiply diluted, heterogeneous, and particular contradictions of citizenship, who will build the anti-capitalist alternative? Who is the actor in this post-developmental scenario? There is no single actor, it turns out, but many: consumers are a key element in organizing alternative exchange systems, as well as non-profit, or not exclusively lucrative associations such as self-managed cooperatives, neo-rural communities, freetime associations, time banking, ethical banks, local exchange systems, or craft associations. From these actors the alternative would be built by the progressive extension of a new logic of non-commodified action within capitalist society. This new logic would be based on non-economic aspects of life, with the gift understood as a triple obligation to give, to receive, and to give back. This logic would imply social relations based on exchange, but that exchange would rely more on reciprocity than on the market. The expansion strategy for this new logic would not consist "in

\footnotetext{
12 Indeed, the cost of reproduction of the labor force is determined according to the historical conditions in which capitalist accumulation is unfolding, and is therefore changeable.
} 
preserving an oasis in the desert of the world market, but gradually extending the sane 'body' to push back the desert, or fertilize" (Latouche 2007, 83).

Within such a heterogeneous set of elements, both actors and instruments appear. Actors can express different positioning vis-à-vis the construction of spaces alternative to capitalist development, but to believe that they can each become the historical subject of change reflects an idealization more than a reality. Undoubtedly, some of these players can be involved in the configuration of better alternatives of capitalism, but not from the instruments indicated, confined more to the peripheral aspects of capitalist exploitation (consumption, trade) that penetrating its core (production processes, work, salaries). These instruments may have more impact, and be more useful, in protecting capitalism through legitimization, making it clear to the citizenry that capitalism can be improved and possibly humanized, and thus eliding the need for holistic and superior alternatives.

D. The critique of modernity generates a certain idealization of traditional societies, that glosses over their most contradictory aspects. Indeed, the rejection of Western modernity, one of the starting points of the post-structuralist turn in development studies, has been translated into a claim for the superiority of the local and the traditional as areas from which elements of the good life to which people aspire are constructed, and against the commodification that created modernity (conceived only as capitalist). The claim which Latouche $(2008,230)$ makes to "renew the thread of the story broken by colonization, development and globalization" implies such an idealization of traditional lifestyles, pre-modern or ancestral. With vivid clarity, this aspect is evidenced in Rahnema $(1997,379)$ :

They had no cars, no Internet and none of the consumer goods to which modern men and women are now addicted. They had no laws and no social security to protect them, no "free press," no "opposition party," no "elected leaders." But they had no less time for leisure, or, paradoxically were no less economically "productive" for the things they needed. And, contrary to the racist clichés in vogue, they were not always governed by cannibals and tyrants. 
However, such claims have been too simplistic in many cases, to the extent that they have omitted the contradictions inherent in all classed societies, and therefore exploitation, domination, and exclusion. The mythification of a pre-capitalist past on the one hand often ignores that it was equally oppressive; on the other hand it subordinates class conflict to cultural contradictions or opposing worldviews, or even removes it from view altogether. Such idealization fails to take into account the effects on people of societies with low levels of productive development, in the form of lacerating deprivation and collective high vulnerability.

The result of these perceptions is a romantic vision that mystifies "the last refuge of the noble savage" (Kiely 1999) and that, ultimately, can generate "ethnochauvinism" (Pieterse 1998). Carried to its ultimate consequences this vision runs the risk of instituting a new moral superiority in place of the old-something which it purports to combat. Indeed, the defense of pre-modern social forms and thought, and the condemnation of modernity, can also be exclusionary and authoritarian against those who, despite everything, still claim modes of economic and social organization meant to liberate from deprivation and lack of comfort-goals historically associated with central aspects of development such as industrialization, electrification, and infrastructure.

\section{E. Post-developmentalism does not confront the real obstacles to development. If} underdevelopment is a Western creation, it becomes difficult to strategize intervention in the face of the drivers of economic polarization and the uneven development inherent in capitalism. Would abandonment of the promotion of development reduce the lacerating asymmetries in the world economy? Analysis of the connections between national and global spheres of capitalism has been critically important to orthodox economics, whether in relativizing the significance of economic polarization or whether by associating the phenomenon with various internal factors. These connections are reflected in the multiple planes (productive, commercial, and financial) in which the mechanisms of polarization operate, all associated with the expansion of capitalism and with the fundamentals of accumulation on a world scale, according neo-Marxist theorists. 
Indeed, some processes and mechanisms-such as productive extraversion, technological dependence, the characteristic horizontal disintegration of enclave economies, the decoupling of wages and productivity in transnationalized industry, the evolution of the terms of trade, the control of marketing channels, the export and repatriation of capital or external debt, among other factors-offer explanations for the persistence and deepening of the global economic polarization. Is it realistic to think that these mechanisms would fail to act in societies that renounced the promotion of development? Could not the proliferation of alternative local foci (as promoted by post-developmentalist approaches) prove comfortably compatible with capital accumulation on a global scale? This is an aspect the consideration and analysis of which should be included in the diagnosis and strategy of any emancipatory alternative. It would seem difficult to configure only local and individual alternative strategies within the framework of a capitalist globalization which involves the universalization of certain economic processes and functional rationales. Practices that expand worldwide must undoubtedly be described as capitalist. Capital advances and with it a planetary and universal story is configured (along with conflicts requiring answers of necessarily the same character). ${ }^{13}$

\section{F. Analyses by post-developmentalists tend to involve mutually exclusive dichotomies} that hinder analysis as well as complex and nuanced arguments. Approaches to dilemmas of the growth vs. degrowth variety tend to exclude more complex formulations such as: What type of growth? For whom and why? For example, highly polluting military industrial growth is not the same as development of technological hubs for a healthcare economy, or boosting growth in sectors linked to needs associated with dependent persons. The dilemma of growth vs. degrowth is based on the assumption that there is only one homogeneous and unique way of consuming or producing. Such infertile dichotomies are also present in the analysis of the relationship between the local (good) and the global (bad), or between tradition (good) and modernity (bad) (Corbridge 1998). The proliferation of such dichotomies

\footnotetext{
${ }^{13}$ In fact, the proliferation of social struggles is often perceived by post-developmentalism as the expression of local struggles specific to particular cultures or particular historical trajectories, rather than as an expression of the (global) contradictions of (globalized) capitalism.
} 
forces pronouncements in which it is difficult to analyze the nuances, conditionings, or wealth of alternatives. ${ }^{14}$

All this is clearly shown in the characterization of modernity as a destroyer of the innate authenticity of the traditional and ancestral, always more harmonious and liberating. Modernity is conceived as capitalist, as occidental, as intrinsically predatory of Nature and distorting of social bonds. This is the starting point of post-modernity, one of the bulwarks of post-developmentalism. This perception, however, does not include the many disparate manifestations of modernity (Wallerstein 1995). Indeed, the way in which modernity has been perceived throughout recent history has been changing, differentiating between what Wallerstein (1995) calls "modern technology" and the "modernity of liberation." While the former has been associated with scientific and technological progress, the latter has meant "being anti-medieval, in an antinomy in which the concept of medieval embodied narrowness, dogmatism, and above all, restrictions of authority. Modernity meant Voltaire shouting 'Écrasez l'infame'” (Wallerstein 1995, 2). The perception of both forms of modernity has oscillated like a pendulum from the 16th century to the present, vindicating or refuting one or the other extreme, according to the historical zeitgeist. So, that which post-structuralism presents as a rejection of modernity would for Wallerstein be the rejection of modern technology in the name of modernity of liberation, so that in fact "that postmodernism is not all postmodern" (Wallerstein 1995, 13). Indeed, of this double notion of modernity, post-developmentalism focuses mainly on modern technology, denouncing its damaging consequences for the planet, while at the same time claiming radical defense of the modernity of liberation.

In short, I consider that the six issues delineated above imply numerous weaknesses in the post-developmentalist approach, indicating its limitations to fostering a pro-positive alternative to capitalist development.

\section{Conclusions}

The post-structuralist shift in development studies, from which post-developmentalism and degrowth have emerged, promoted a proliferation of analyses and proposals that

14 "To be 'for' or 'against' ... is too simple [a] position" (Pieterse 1998, 345). 
traced paths in opposition to capitalist development. However, that shift also worked against any further developmental efforts. In this way both capitalist development and its traditional criticisms, nourished mainly by Marxist theories of development, found themselves the center of a new criticism and the object of efforts to deconstruct an idea of development now considered the expression of imposed occidental cultural hegemony (a new belief, a modern religion).

Following a brief systematization of the central aspects of postdevelopmentalism, the purpose of this paper has been to illuminate the shortcomings of post-developmentalist diagnoses and proposals in terms of postdevelopmentalism's viability as a robust alternative to dominant approaches, or as a provider of elements from which to build an emancipatory alternative to capitalist development. However, it is necessary to recognize some contributions of postdevelopmentalist criticism that shed light its increasing attractiveness to some academic, social or political areas. First, post-develomentalist criticism has contributed decisively to the awareness of the physical and environmental limits of capitalism's production and consumption patterns. Second, the post-developmentalist approach has favored the joint analysis of the different challenges that make today's societies more complex, and in particular the role of women in capitalist economic reproduction. And third, post-developmentalist criticism has identified the risks of neoextractivism associated with new development strategies in some Latin American countries as merely new forms of capitalist modernization. Thus, authors associated with post-development such as Alberto Acosta or Eduardo Gudynas spearhead the critique of the insufficiencies and renunciations of governments such as Bolivia or Ecuador.

Despite these contributions of post-developmentalism, this paper has been shown that this approach suffers from a number of limitations, leading to several conclusions. First, post-developmentalism does not offer conceptual tools capable of transcending capitalism, nor does it demonstrate the ability to inspire innovative designs for real social change. In this sense its anti-capitalist critique is not especially radical. Furthermore, its proposals are compatible with capitalism and are indeed accommodated to capital. Although defenders of degrowth have claimed a monopoly 
on anti-capitalist struggle, neither private ownership of the factors and means of production nor the commodification of social relations through the labor market, nor patterns of appropriation and private accumulation of wealth-precisely the mechanisms through which capitalist exploitation occurs-occupy central positions in degrowth contributions. Capital (as commodity, as money, and as a social relationship) is not integrated into the interpretative and political schemes of postdevelopmentalism and degrowth. Instead, the emphasis on growth forgoes the denunciation of the essential features of capitalism. Will the end of growth mean the end of class exploitation? No precapitalist system was "developmental," but all were exploitative. Far from analyzing and disrupting the mechanisms of capitalist exploitation, the post-developmentalist analysis and proposals seem to find only fragmented and disconnected spaces for accommodation as a strategy to begin construction of a new ideal that, while nominally opposed capitalist universality, depends only on local responses.

Second, observations regarding the costs of development should not obscure the costs of underdevelopment, and therefore it is necessary to address the essential factors that perpetuate underdevelopment. Only this would constitute a development strategy. The skepticism and rejection shown by post-structuralism towards efforts to identify and understand the evolutionary trends of the world economy are precise expressions of their diagnosis. Based on that diagnosis underdevelopment is mere invention, a story that exists as concept, frustrating analytical efforts that might seek to articulate emancipatory strategies in order to address obstacles to development.

Third, post-developmentalist authors tend to waive objectives whose desirability and universality was previously unquestionable. They believe that no such universality exists as corollary to their reverential respect for singularity (of conflicts, subjects and solutions). However, any emancipatory alternative to capitalist development should aim toward proposing and building scenarios of universal validity, because the validity and deployment of capitalist development is likewise universal in scope. I believe that there are situations to which any emancipatory strategy should aspire. It would be legitimate, for example, to recognize as a universal aim that all the world's inhabitants have access to a rich, varied, and balanced diet, or to potable 
water, or to medical care that is as comprehensive as current science allows. Claiming these objectives, which capitalist development has not achieved for the entire planet, does not imply a legitimization of Western culture domination. These are demands that suit every time and place, in that they are conditions necessary to ensuring the perpetuation of any society or culture. In short, there exist certain aspects of human action that range beyond the creation or preservation of culture, that is to say, aspects that are neither specific nor unique to a particular community but that are essential components of human nature. Beyond the particulars of societies and cultures, aspiration to an economic, social, and political project of emancipation born of universal objectives is a profoundly human goal. Why not call objectives such as these "development"?

\section{References}

Acosta, Alberto. 2010. "Hacia la declaración universal de los derechos de la Naturaleza. Reflexiones para la acción" [Towards the Universal Declaration of the Rights of Nature. Reflections for Action]. https://systemicalternatives.org/2014/02/13/hacia-ladeclaracion-universal-de-los-derechos-de-la-naturaleza/.

Amin, Samir. 1999. El capitalismo en la era de la globalización [Capitalism in the Age of Globalization. The Management of Contemporany Society]. Barcelona: Paidós.

Amorós, Miguel. 2012. Salidas de emergencia [Emergency Exits]. Logroño: Pepitas deCalabaza.

Blomström, Magnum and Björn Hettne. 1984. Theory in Transition: The Dependency Debate and Beyond Third World. London: Zed Books.

Baudrillard, Jean. 1983. Simulations. Translated by Paul Foss, Paul Patton, and Philip Beitchman. New York: Semiotext(e), Inc.

Ceceña, Ana Esther. 2013. "Subvertir la modernidad para vivir bien" [Subverting Modernity to Live Well]. In Crisis civilizatorias y superación del capitalismo [Civilizational Crisis and Overcoming of Capitalism], edited by Raúl Ornelas, 91-128. México DF: Institute of Economic Research. 
Corbridge, Stuart. 1998. "'Beneath the Pavement Only Soil': The Poverty of Post-

Development." Journal of Development Studies 36(4): 138-148.

Escobar, Arturo. 1992a. "Reflections on 'Developmnet': Grassroots Aproaches and Alternatives Devlopment in the Third World." Futures 24(5): 411-436.

Escobar, Arturo. 1992b. "Planning." In The Development Dictionary, edited by Wolfgang Sachs, 132-145. London: Zed Books.

Escobar, Arturo, 1995. Encountering Development: The Making and Unmaking of the Third World. Princeton: Princeton University Press.

Esteva, Gustavo. 1992. "Development." In The Development Dictionary, edited by Wolfgang Sachs, 7-25. London: Zed Books.

Esteva, Gustavo. 1985. "Beware of Participation." Development: Seeds of Change 3: 7779.

Gandhi, Mahatma. 1997. "The Quest for a Simple Life: My Idea of Swarej." In The Postdevelopment Reader, edited by Majid Rahnema and Victoria Bawtree, 306-307. Zen Books: London.

García, Ernest. 2012. "Degrowth, the Past, the Future, and the Human Nature". Futures 44: 546-552.

García, Santiago, Juan M. Ramírez-Cendrero, and Alejandro Santillán. 2015. “Desarrollo y alternativas al desarrollo en Ecuador. Economía comunitaria: la experiencia de Sarayaku en la Amazonía" [Development and Alternatives to Development in Ecuador. Communitarian Economy: the Experience of Sarayaku in the Amazon]. Paper presented at the Third Congress of Economy, National Polytechnic School and National Planning and Development Secretariat (Senplades), Quito, July 13-17.

Georgescu-Roegen, Nicholas. 1975. "Energy and Economic Myths." Southern Economic Journal 41(3): 347-381.

González Reyes, Luis. 2010. “Decrecimiento y relaciones centro-periferia” [Degrowth and Core-Periphery Relations]. In Decrecimiento. Sobre lo que hay que cambiar en la 
vida cotidiana [Decrease. About What Must Change in Everyday Life], edited by Carlos Taibo, 225-237. Madrid: Los Libros de la Catarata.

Hamilton, Clive. 2008. El fetiche del crecimiento [Growth Fetish]. Pamplona: Laetoli. Illich, Ivan. 1997. "Development as Planned Poverty." In The Postdevelopment Reader, by Rahnema, Majid, and Victoria Bawtree, 94-102. London: Zen Books.

Kiely, Ray. 1999. "The Last Refuge of the Nobile Savage? A Critical Assessment of PostDevelopment Theory." European Journal of Development Research 11(1): 30-55.

Latouche, Serge. 2007. Sobrevivir al desarrollo: de la descolonización del imaginario colectivo a la construcción de una sociedad alternativa [Surviving the Development: from the Decolonization of Collective Imagination to the Construction of an Alternative Society]. Barcelona: Icaria.

Latouche, Serge. 2008. La apuesta por el decrecimiento. ¿Cómo salir del imaginario dominante? [The Commitment to Decrease. How to Get out of the Dominant Imaginary?]. Barcelona: Icaria.

Latouche, Serge 2009. Decrecimiento y postdesarrollo. El pensamiento creativo contra la economía del absurdo [Decrease and Post-Development. Creative Thinking Against the Economy of Absurdity]. Barcelona: El Viejo Topo.

Leff, Enrique. 2008. “Decrecimiento o desconstrucción de la economía: hacia un mundo sustentable" [Decrease or Deconstruction of Economy: Towards a Sustainable World]. Polis 7(21): 81-90.

Martínez Alier, Joan. 2009. "Socially Sustainable Economic De-growth." Development and Change 40(6): 1099-1119.

Navarro, Vicenç. 1978. La medicina bajo el capitalismo [Medicine under Capitalism]. Barcelona: Crítica.

Parfitt, Trevor. 2002. The End of Development: Modernity, Postmodernity and Development. London: Pluto Press. 
Peet, Richard and Elaine Hartwick. 1999. Theories of Development. New York: The Guilford Press.

Pieterse, Jan Nederveen. 1998. “My Paradigm or Yours? Alternative Development, Post-Development, Reflexive Development." Development and Change 29(2): 343-373.

Pieterse, Jan Nederveen. 2000. "After Post-Development." Third World Quarterly 21: 175-191.

Rahnema, Majid. 1997. "Towards Post-Development: Searching for Signposts, a New Language and New Paradigms." In The Post-Development Reader, edited by Rahnema, Majid, and Victoria Bawtree, 377-403. London: Zed Books.

Rahnema, Majid and Victoria Bawtree, eds. 1997. The Postdevelopment Reader. London: Zen Books.

Riechmann, Jorge. 1995. "Desarrollo sostenible: la lucha por la interpretación" [Sustainable Development: the Struggle for Interpretation]. In De la economía a la ecología [From Economy to Ecology], edited by José Manuel Naredo, Jorge Riechmann, Roberto Bermejo, Antonio Estevan, Carlos Taibo, Juan Carlos Rodríguez, and Joaquí Nieto, 11-36. Madrid: Trotta.

Rist, Gisbert. 2002. El desarrollo: historia de una creencia occidental [Development: History of a Western Belief]. Madrid: Los Libros de la Catarata.

Roca, Jordi. 2007. “La crítica al crecimiento económico desde la economía ecológica y las propuestas de decrecimiento" [The Criticism to Economic Growth from the Ecological Economy and the Proposals for Degrowth]. Economía Ecológica 33: 13-17.

Sachs, Ignacy. 1980. Strategies de l'écodeveloppement. Paris: Editions Ouvries.

Sachs, Wolfgang. 1992. "Introduction." In The Development Dictionary, edited by Wolfgang Sachs, 1-5. London: Zed Books.

Sachs, Wolfgang. 1997. "The Need for the Home Perspective." In The Postdevelopment Reader, edited by Majid Rahnema and Victoria Bawtree, 290-300. London: Zen Books. 
Seers, Dudley. ed. 1981. Dependency Theory: A Critical Reassessment. London: Frances Pinter.

Shiva, Vandana. 1988. Staying Alive: Women, Ecology and Development. London: Zed Books.

Taibo, Carlos. 2009. En defensa del decrecimiento. Sobre capitalismo, crisis y barbarie [In Defense of Degrowth. About Capitalism, Crisis and Barbarity]. Madrid: Los Libros de la Catarata.

Taibo, Carlos. 2014. ¿Por qué el decrecimiento? Un ensayo sobre la antesala del colapso [Why degrowth? An Essay About the Threshold of Collapse]. Barcelona: Los Libros del Lince.

Trainer, Ted. 2012. “De-growth: Do you Realise What it Means?” Futures 44: 590-599.

Wallerstein, Immanuel. 1995. “¿El fin de qué modernidad?” [The End of What Modernity?]. Sociológica 27: 1-14. 